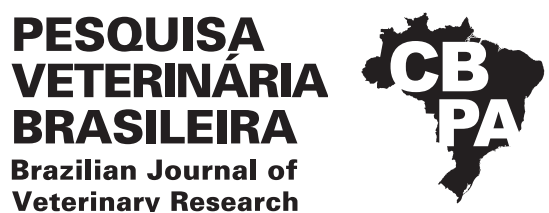

\title{
Epigenetic characterization of the H19/IGF2 locus in calf clones placenta ${ }^{1}$
}

\author{
Natalia S. Costa ${ }^{2,3 *}$ (D), Márcia M. Silveira ${ }^{2}$, Luna N. Vargas² ${ }^{2}$ Alexandre R. Caetano ${ }^{4}$, \\ Rodolfo Rumpf ${ }^{5}$ and Maurício M. Franco ${ }^{2,3}$
}

\begin{abstract}
Costa N.S., Silveira M.M., Vargas L.N., Caetano A.R., Rumpf R. \& Franco M.M. 2020. Epigenetic characterization of the H19/IGF2 locus in calf clones placenta. Pesquisa Veterinária Brasileira 40(12):1063-1072. Laboratório de Reprodução Animal, Embrapa Recursos Genéticos e Biotecnologia-Cenargen, Parque Estação Biológica, Avenida W/5 Norte (final), Cx. Postal 02372, Brasília, DF 70770-917, Brazil. E-mail: natalia.souzacosta15@gmail.com

Somatic Cell Nuclear Transfer (SCNT-Cloning) is a promising technique in many areas and is based on genetically identical individuals. However, its efficiency is low. Studies suggest that the leading cause is inadequate epigenetic reprogramming. This study aimed to characterize the methylation pattern of the exon 10 regions of the IGF2 gene and the Imprinting Control Region (ICR) of the $\mathrm{H} 19$ gene in the placenta of cloned calves. For this study, female and male cloned calves presenting different phenotypes were used. Genomic DNA from these animals' placenta was isolated, then treated with sodium bisulfite and amplified to the ICR/ H19 and IGF2 loci. PCR products were cloned into competent bacteria and finally sequenced. A significant difference was found between controls and clones with healthy phenotypes for the ICR/H19 region. In this region, controls showed a hemimethylated pattern, as predicted in the literature due to this region has an imprinted control, while clones were showed less methylated. For the IGF2, no significant differences were found between controls and clones. These results suggest that different genomic regions in the genome may be independently reprogrammed and that failures in reprogramming the DNA methylation patterns of imprinted genes may be one of the causes of the low efficiency of SCNT.
\end{abstract}

INDEX TERMS: Epigenetic, H19, IGF2, locus, placenta, calf, cloning, imprinting, bovine.

\begin{abstract}
RESUMO.- [Caracterização epigenética do locus H19/ IGF2 na placenta de bezerros clones.] A Transferência Nuclear de Células Somáticas (TNCS-Clonagem) é uma técnica promissora em várias áreas, e se baseia na produção de indivíduos geneticamente idênticos. No entanto, sua eficiência é baixa. Estudos sugerem que a principal causa seja uma reprogramação epigenética inadequada. 0 objetivo desse trabalho é caracterizar o padrão de metilação da região éxon 10 do gene IGF2 e da Região Controladora de Imprinting
\end{abstract}

\footnotetext{
${ }^{1}$ Received on August 25, 2019.

Accepted for publication on January 16, 2020.

${ }^{2}$ Laboratório de Reprodução Animal, Embrapa Recursos Genéticos e Biotecnologia, Parque Estação Biológica, Avenida W/5 Norte (final), Cx. Postal 02372, Brasília, DF 70770-917, Brazil.*Corresponding author: natalia.souzacosta15@gmail.com

${ }^{3}$ Graduate Program in Veterinary Sciences, Faculdade de Medicina Veterinária, Universidade Federal de Uberlândia (UFU), Rodovia BR-050 Km 78, Campus Glória, Uberlândia, MG 38410-337, Brazil.

${ }^{4}$ Embrapa Recursos Genéticos e Biotecnologia, Parque Estação Biológica, Avenida W/5 Norte (final), Cx. Postal 02372, Brasília, DF 70770-917, Brazil.

${ }^{5}$ Geneal Genética e Biotecnologia Animal, Rodovia BR-050, Km 184, Uberaba, MG 38038-050, Brazil.
}

(ICR) do gene $H 19$ na placenta de bezerros clonados. Para a execução do trabalho foram selecionados clones bovinos fêmeas e machos, apresentando diferentes fenótipos. 0 DNA da placenta desses animais foi extraído, e em seguida foi tratado com bissulfito de sódio e amplificado para os loci ICR/H19 e IGF2. Os produtos da PCR foram clonados em bactérias competentes e, por fim, sequenciados. Foi encontrada uma diferença significativa entre os controles e os clones com fenótipos saudáveis para a região da ICR/H19. Nesta região, os controles tiveram um padrão hemimetilado, como previsto pela literatura, devido essa região ser imprinted. Enquanto os clones encontravam-se menos metilados. Para a região do éxon 10 do IGF2, não foi encontrada diferença significativa entre controles e clones. Estes resultados sugerem que as diferentes regiões do genoma podem se reprogramar independente umas das outras e que falhas na reprogramação do padrão de metilação do DNA de genes imprinted podem ser uma das causas da baixa eficiência da TNCS.

TERMOS DE INDEXAÇÃO: Epigenética, locus, H19, IGF2, placenta, bezerros, clonagem, imprinting, bovino. 


\section{INTRODUCTION}

Somatic Cell Nuclear Transfer Cloning (SCNT) is one of the promising biotechniques in reproduction. This technique is based on the production of genetically identical individuals. This is because the oocyte cytoplasm contains specific epigenetic machinery that can reprogram the nucleus of somatic cells in an undifferentiated state, which can generate a viable embryo (Wilmut et al. 1997). The SCNT has potential applications, such as in the production of animals of high commercial value, in biomedicine with the use of xenotransplants, in the maintenance of animals at risk of extinction (Cibelli et al. 1998), and in the production of transgenic and genetically edited animals (Petersen 2017).

After Dolly, the first mammal to be cloned, several species have already been successful with NT. (Wilmut et al. 1997). However, its efficiency remains low (Rodriguez-Osorio et al. 2012). The rates of embryos with full-term development and birth are mainly below $5 \%$ (Wells et al. 1999). The main cause for the aberrant phenotypes found in cloning is believed to be related to failures in the epigenetic reprogramming of the nucleus donor cell, leading to changes in global gene expression and imprinted genes (Mann et al. 2003).

Epigenetics is an area of genetics that studies gene function changes that are not directly related to changes in the primary DNA sequence (Dupont et al. 2009). Epigenetic profiles can persist for generations, so they are inheritable. However, external factors can be altered, such as nutrition, environment, use of drugs, toxins, etc. (Reik 2007).

Research has shown that assisted reproduction techniques (ARTs) cause epigenetic changes in the conceptuses. For example, at SCNT, embryos are exposed to different microenvironments, in vitro maturation, and in vitro cultivation, which can interfere with their development (Wells et al. 1999). It can be concluded that these techniques also act as an external factor, assessing the potential for term development or even in the conception of healthy animals (Lucifero et al. 2004, Smith et al. 2012, Urrego et al. 2014).

DNA methylation is one of the prominent epigenetic marks responsible for epigenetic inheritance between generations (Migicovsky \& Kovalchuk 2011). This epigenetic mark is characterized by the methyl group (CH3), linked to a cytosine that precedes guanine in a place called 5'-CpG-3 '(Smith \& Meissner 2013). DNA methylation plays a fundamental role in controlling gene expression, maintaining genome integrity, regulating genomic imprinting, and inactivating the $\mathrm{X}$ chromosome, indispensable in cell differentiation and early development (Dean et al. 2003).

Gametes are responsible for transmitting genetic and epigenetic information to the next generation. They undergo extensive epigenetic reprogramming, making these cells suitable for fertilization and embryogenesis (Reik 2007). Stable patterns of genomic methylation are generally inherited in differentiated somatic cells, but only in gametogenesis, and during the beginning of embryogenesis, these patterns are reprogrammed in two waves of demethylation remethylation (Fig.1), (Reik 2007). In clones, this reprogramming is done in a shorter period and a different cellular context when compared to normal development, increasing the probabilities of failures in the process (Murrell et al. 2001).

Genomic imprinting is an epigenetic mechanism that causes monoallelic expression of genes according to the allele's parental origin. That is, of the two inherited copies, only one allele is expressed. Its main epigenetic mark is DNA methylation, established during gametogenesis (Barlow \& Bartolomei 2014). Imprinted genes are generally related to behavior, metabolism, fetal growth, and postnatal development (Daelemans et al. 2010). Two imprinted genes essential in embryonic growth and development are IGF2 and H19 (Gebert et al. 2006). The IGF2 is responsible for inducing fetal growth and development and is related to the placenta's development by its mitogenic power, promoting cell division and differentiation (O'dell \& Day 1998, Gebert et al. 2006). The $\mathrm{H} 19$ gene, on the other hand, regulates a non-coding RNA molecule responsible for inhibiting IGF2 expression (Brannan et al. 1990). As it has an imprinted pattern, only the maternal allele is transcribed. The opposite is true with IGF2, for which only the paternal allele is expressed (Fig.2) (Daelemans et al. 2010).

This study aimed to characterize the methylation pattern of the differentially methylated region of exon 10 of the IGF2 gene and the imprinting controlling region of the IGF2/H19 locus in the fetal placenta of cloned calves.

\section{MATERIALS AND METHODS}

The experiment was developed at "Laboratório de Reprodução Animal" of "Embrapa Recursos Genéticos e Biotecnologia" in Brasília, Distrito Federal, Brazil.

Experimental design. This study's biological material was fetal cotyledon of the bovine placenta of the Nellore breed (Bos taurus indicus). All the material was collected at "Geneal Genética e Biotecnologia Animal", in Uberaba/MG. With this material, the DMR methylation pattern of exon 10 of the IGF2 gene and ICR H19 was analyzed in the placenta of female and male clones, with healthy and aberrant phenotypes. The clones were aberrant when they presented at least one of the following phenotypes: thick umbilical cord, mortality in the first week, LOS, placental edema, large placentoma, meconiumtinged placental fluid. As controls, placentas from two animals, one male, and one female, produced by artificial insemination, were used (Table 1). The Ethics Committee on Animal Use (protocol CEUA No. 078/16) of the "Universidade Federal de Uberlândia", Minas Gerais, Brazil, approved all procedures performed.

Isolation of genomic DNA. Genomic DNA was isolated by the salting-out method as described by Biase et al. (2002). Then, it was submitted to quality evaluation by electrophoresis in $1 \%$ agarose gel. Concentration and purity were assessed with a NanoDrop spectrophotometer (Thermo Fisher Scientific, Waltham/MA, EUA). Genomic DNA samples were stored at $-20^{\circ} \mathrm{C}$.

Treatment of genomic DNA with sodium bisulfite. This technique allows DNA methylation analysis, as it converts unmethylated cytosines into uracils through sodium bisulfite. The kit used for this treatment was EZ DNA Methylation ${ }^{\circledR}$ (Zymo Research, Irvine/CA, USA), following the manufacturer's recommendations. The treated DNA was stored at $-80^{\circ} \mathrm{C}$. According to Zhang et al. (2016), the methylation pattern is classified as hypomethylated ( $0 \%$ to $20 \%$ ), hemimethylated $(21 \%$ to $50 \%$ ), and hypermethylated (51\% to $100 \%$ ).

DNA samples treated with sodium bisulfite were subjected to PCR using the thermal cycler T100 Thermal Cycler (Bio-Rad). The regions of interest were the ICR of the $\mathrm{H} 19$ gene and the DMR of exon 10 of the IGF2 gene. The sequences of the primers used for DNA amplification, the GenBank access number, the CpG island position, the location and size of the amplified fragments are shown in Table 2. 
PCR reactions for both regions were performed using $1 \mathrm{x}$ buffer solution; $2.0 \mathrm{mM} \mathrm{MgCl} ; 0.4 \mathrm{mM}$ dNTP; $1 \mathrm{U}$ of Taq DNA Polymerase Platinum (Invitrogen, Carlsbad/CA, USA) and $1 \mathrm{uM}$ of each of the primers (forward and reverse), the volume being adjusted to $20 \mathrm{uL}$ with Milli-Q water. The amplification conditions are described in Table 3.

The amplicons were subjected to electrophoresis in $1.8 \%$ agarose gel, stained with ethidium bromide $(10 \mathrm{mg} / \mathrm{ml})$ at a constant electric current of 50mA in $0.5 \mathrm{X}$ TBE medium. The marker used was $1 \mathrm{~Kb}$ Plus molecular weight DNA Ladder ${ }^{\circledR}$ (Invitrogen, Carlsbad/CA, USA). The gel was photographed on a photo documenter (BioRad). According to the manufacturer, the amplicons were cut out of the gel and purified using the Wizard ${ }^{\circledR}$ SV Gel and PCR Clean-Up System kit (Promega, Madison/WI, USA) standards. The samples were then quantified on a NanoDrop ${ }^{\circledR}$ spectrophotometer (ND-1000) (Thermo Scientific, Asheville/NC, USA).
Cloning of PCR products and extraction of plasmid DNA. The TOPO TA Cloning ${ }^{\circledR}$ (Invitrogen) vector was used to clone the amplicons. DH5 $\alpha$ cells were transformed using a heat shock protocol. Then they were placed in a $90 \times 15 \mathrm{~mm}$ petri dish containing agar with $100 \mathrm{ug} / \mathrm{mL}$ ampicillin, $40 \mu \mathrm{L}$ of $20 \mathrm{mg} / \mathrm{mL} \mathrm{X-Gal} \mathrm{(Sigma),} \mathrm{and} 4 \mu \mathrm{L}$ of 0.1 M IPTG (Sigma), followed by plate inversion and incubation in an oven at $37^{\circ} \mathrm{C}$ for 14 hours.

The white colonies were selected to be grown in Luria Bertani (LB) medium plus ampicillin at $100 \mathrm{ug} / \mathrm{mL}$. With a sterile wooden toothpick, the colonies were removed and deposited inside a $15 \mathrm{~mL}$ collection tube containing $3 \mathrm{~mL}$ of LB medium. The tubes were stirred at $250 \mathrm{rpm}$ at $37^{\circ} \mathrm{C}$ for 16 hours in a shaker (New Brunswick Scientific Co, NJ, USA). According to the plasmid mini-preparation protocol, half the contents of the tubes were used for the extraction of plasmid DNA. The dry pellets were eluted in $20 \mu \mathrm{L}$ of deionized water and the DNA quantified in a spectrophotometer. NanoDrop ${ }^{\circledR}$ (ND- 1000) (Thermo Scientific, Asheville/NC, USA).

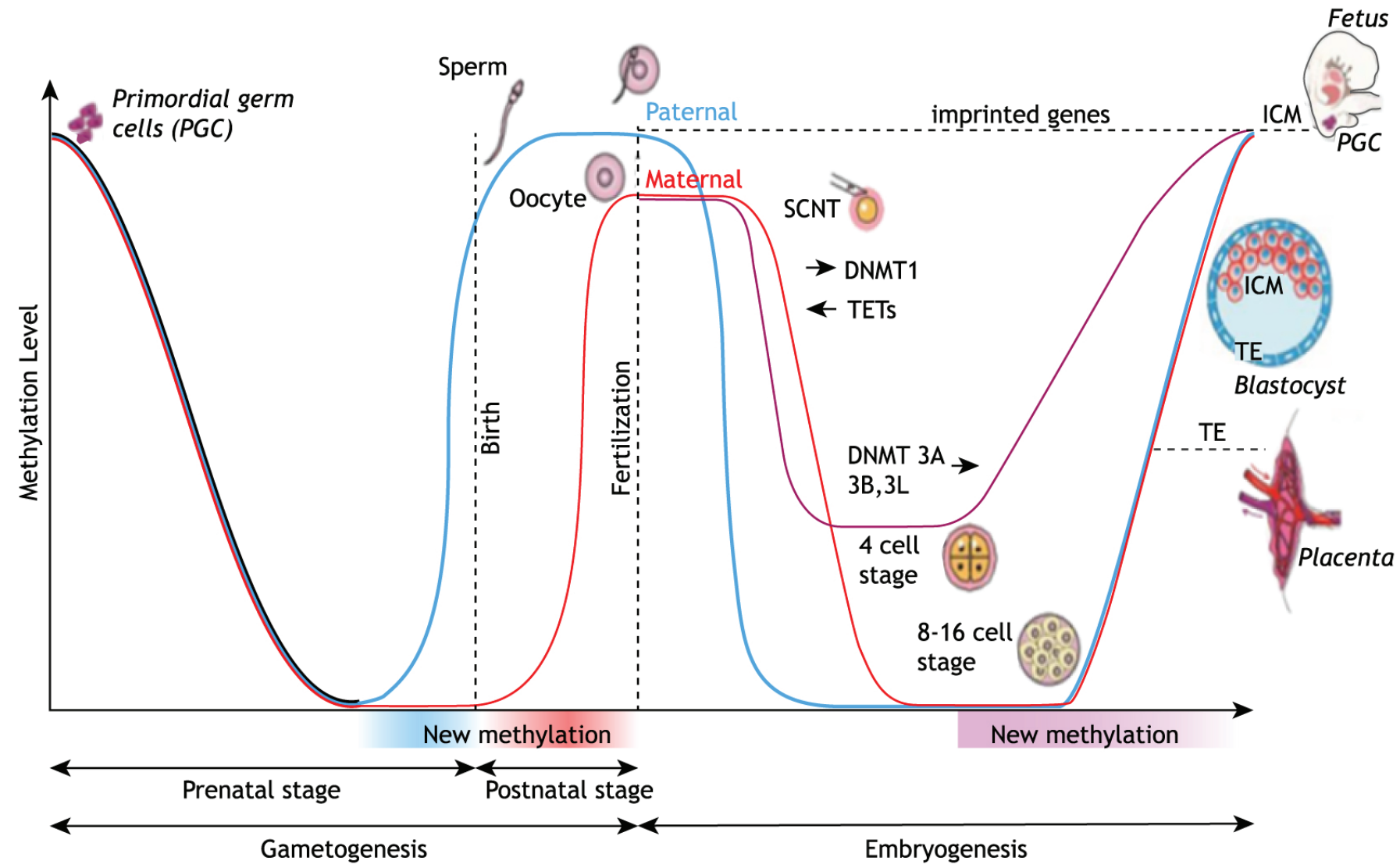

Fig.1. Epigenetic reprogramming in mammals. In gametogenesis, the primordial germ cells (PGC), paternal and maternal genomes (blue and red lines, respectively) undergo global demethylation of the genome, including also in differentially methylated regions of germline (gDMRs) (black line). In male fetuses, methylation again begins during fetal life (prenatal stage), and at birth, the paternal genome already has a high level of methylation (postnatal stage) (blue line). In female fetuses, the acquisition of methylation again begins whenever an oocyte is recruited to proceed with oogenesis but is only completed after puberty, with appropriate hormonal stimuli (postnatal stage) (red line). In embryogenesis, after fertilization and before DNA replication, TETs enzymes actively demethylate the paternal genome (blue line). Global remodeling occurs with the exchange of protamines for maternal histones (not shown). In contrast, the maternal genome is demethylated after several cell divisions by a passive mechanism (red line) due to the removal of DNMT1 from the nucleus. In bovine embryos, starts again, methylation of the two parental genomes, catalyzed by DNMTs 3A, 3B, and $3 \mathrm{~L}$, begins around the 8-16 cell stage. The purple line represents the reprogramming of DNA methylation in clone embryos, showing that an inefficient loss of methylation occurs after nuclear transfer, and the methylation starts again early, in the 4-cell stage. The first cell differentiation occurs in the blastocyst phase, generating the trophoblast cells (TE), which will originate from the placenta, and the internal cell mass (ICM), originating from the fetus. The dashed gray lines represent the imprinted genes' alleles, with the upper line representing the methylated alleles and the lower, the non-methylated alleles. The graph is not represented in scales and does not show the exact proportion of methylation. Adapted from Vargas (2018). 

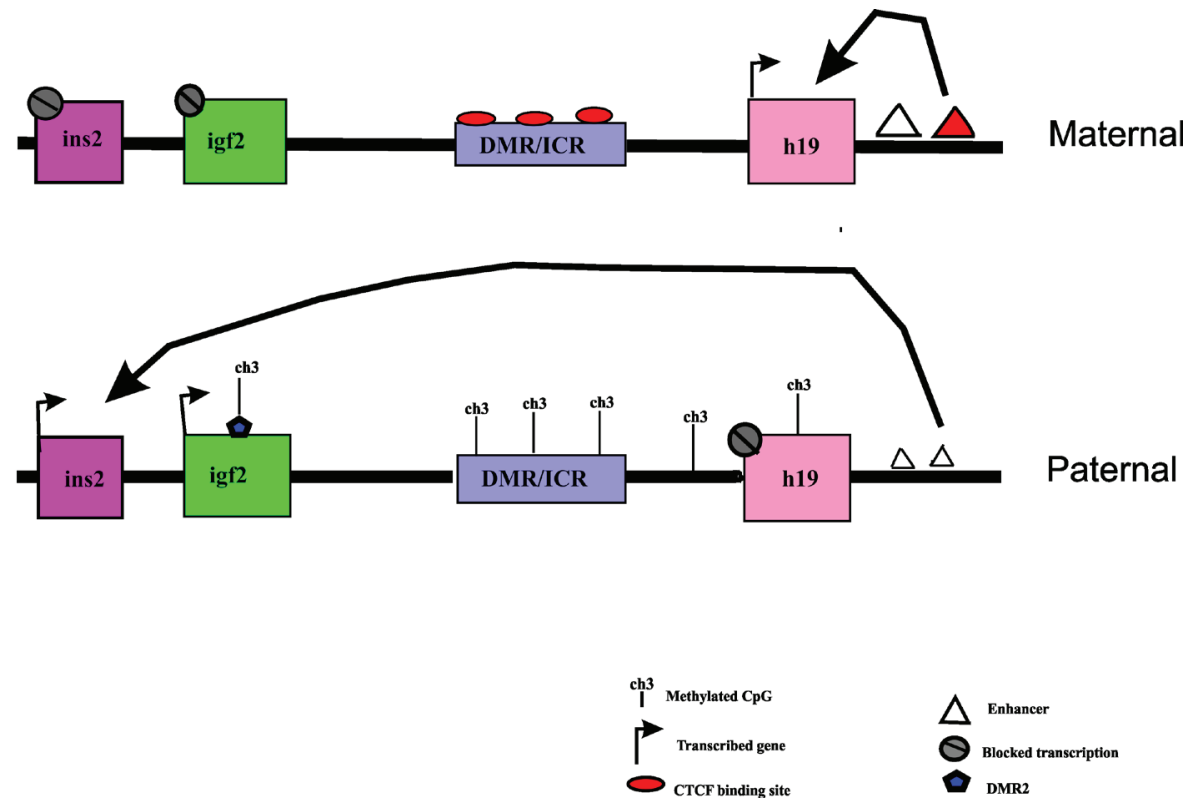

Fig.2. Regulation mechanism of the H19 and IGF2 gene. This figure depicts the maternal and paternal alleles for the IGF2/H19 locus. In the maternal allele, CTCF binds to the demethylated region of ICR/H19, blocking enhancers' binding to the promoter region of the IGF2 gene, silencing it. Enhancers promote the transcription of the H19 gene in the maternal allele. In the paternal allele, the ICR/H19 region is methylated. Therefore, there is no binding of the CTCF, and the enhancers approach the IGF2 promoter, triggering the IGF2 transcription. Adapted from Bartolomei (2009).

Table 1. Animals selected for the study, according to sex, phenotypes and viability (survival in the first week of birth)

\begin{tabular}{|c|c|c|c|c|}
\hline \multicolumn{5}{|c|}{ Animals selected for the study } \\
\hline Individual & Sex & Phenotypes & Viability & Classification \\
\hline Clone & Female & No changes & Survived the 1st week & Healthy \\
\hline Clone & Female & Large placentoma, LOS, thick umbilical cord & 1st week mortality & Aberrant \\
\hline Clone & Male & No changes & Survived the 1 st week & Healthy \\
\hline Clone & Male & LOS, placenta edema, thick umbilical cord, large placentoma, placental-meconium fluid & 1st week mortality & Aberrant \\
\hline A.I. & Female & No changes & Survived the 1 st week & Healthy \\
\hline A.I. & Male & No changes & Survived the 1 st week & Healthy \\
\hline
\end{tabular}

Material provided by the company “Geneal Genética and Biotecnologia Animal”, Uberaba/MG; A.I. = artificial insemination.

Table 2. Identification of the gene, primer sequences, GenBank access code, location of the primers, position of the CpG island and size of the amplified fragment

\begin{tabular}{|c|c|c|c|c|c|}
\hline Gene & Sequence of primers $\left(5^{\prime}->3^{\prime}\right)$ & Access to GenBank & Number of CpGs sites & Island position $\mathrm{CpG}$ & Amplicon size \\
\hline \multirow[t]{2}{*}{ ICR/H19 } & F: GGTGATATAGGGTAGTGTGTAGAGGATATTGGGG & Nc-037356.1 & 23 & DMR1 & 423bp \\
\hline & R: ATACTACTAAAAATCCСATAAAAAAAATCTCTCTC & & & ICR/H19* & \\
\hline IGF2 & F: TGGGTAAGTTTTTTTAATATGATATT & X53553.1 & 28 & Exon 10 & $455 \mathrm{bp}$ \\
\hline
\end{tabular}
R: TTTAAAACCAATTAATTTTATACATT

$\mathrm{F}=$ forward, $\mathrm{R}$ = reverse, bp = base pairs, DMR1 = differentially methylated region 1 within the ICR/H19*, Primer IGF2 = Gebert et al. (2006), Primer ICR/H19 = Jenna et al. (2014).

Table 3. Amplification conditions used in the PCR for the ICR/H19 imprinting controlling region and for the differentially methylated region of the IGF2 gene

\begin{tabular}{|c|c|c|c|c|c|}
\hline \multirow{2}{*}{ Locus } & \multirow{2}{*}{ Initial denaturation } & \multicolumn{3}{|c|}{ Cycles (40 for ICR and 45 for IGF2) } & \multirow{2}{*}{ Final extension } \\
\hline & & Denaturation & Annealing & Extension & \\
\hline \multirow[t]{2}{*}{ ICR/H19 } & $94^{\circ} \mathrm{C}$ & $94^{\circ} \mathrm{C}$ & $58^{\circ} \mathrm{C}$ & $72^{\circ} \mathrm{C}$ & $72^{\circ} \mathrm{C}$ \\
\hline & $3 \mathrm{~min}$ & $40 \mathrm{~s}$ & $1 \mathrm{~min}$ & $1 \mathrm{~min}$ & $15 \min$ \\
\hline \multirow[t]{2}{*}{ DMR IGF2 } & $94^{\circ} \mathrm{C}$ & $94^{\circ} \mathrm{C}$ & $45^{\circ} \mathrm{C}$ & $72^{\circ} \mathrm{C}$ & $72^{\circ} \mathrm{C}$ \\
\hline & $3 \mathrm{~min}$ & $40 \mathrm{~s}$ & $1 \mathrm{~min}$ & $1 \mathrm{~min}$ & $15 \min$ \\
\hline
\end{tabular}

$\overline{\mathrm{CRI}}=$ controlling region of imprinting, DMR = differentially methylated region. 
Plasmidial DNA sequencing and sequence analysis. The digestion of the miniprep samples for confirmation of cloning used the ECOR1 enzyme (5U), the H buffer (1X), and the miniprep DNA (2ul) adjusted with Milli-Q water to $10 \mathrm{uL}$. The samples were incubated in a water bath at $37^{\circ} \mathrm{C}$ overnight. The digestion products were submitted to electrophoresis in $1.5 \%$ agarose gel stained with ethidium bromide $10 \mathrm{mg} / \mathrm{mL}$ to confirm fragments' presence. Plasmidial DNA samples ( $\sim 300 \mathrm{ng}$ ) were sequenced using the universal primer M13 reverse by the Sanger method.

The Chromas ${ }^{\circledR}$ program verified the quality of the sequencing. For the quantification of the methylation pattern, the QUMA program was used, comparing the sequences obtained with the reference deposited in GenBank, both for ICR/H19 (X53553.1) and IGF2 (Nc037356.1). In this study, only rows that presented at least $97 \%$ of conversion by sodium bisulfite - when the conversion rate of cytosines not followed by guanine and lines with at least 95\% identity was observed - when compared with the reference sequence.

Statistical analysis. For statistical analysis, the GraphPad Prism software ${ }^{5}$ was used. Kruskal-Wallis or Mann-Whitney analysis compared the animals experimental treatments. The means and standard deviations were verified using the Action version 2.9 program. The results were described as mean \pm standard error of the mean. $P$-value $\leq 0.05$ denotes a statistically significant difference.

\section{RESULTS}

The ICR/H19 showed the following methylation percentages: $20.916 \pm 7.016 \%$ for a female clone with a healthy phenotype, $24.907 \pm 9.785 \%$ for a male clone with a healthy phenotype, $32.592 \pm 10.598 \%$ for a female clone with aberrant phenotype, and $28.584 \pm 9.771 \%$ for clone male with aberrant phenotype. The percentage of methylation for the control group was $30.06 \pm 10.910 \%$ for females and $75.016 \pm 10.667 \%$ for males (Fig.3).

Concerning exon 10 of IGF2, the following percentages of methylation were found: $20.644 \pm 11.968 \%$ for a female clone with a healthy phenotype, $35.571 \pm 16.065 \%$ for a male clone with a healthy phenotype, $34.34 \pm 13.909 \%$ for a female clone with aberrant phenotype, and $10.727 \pm 8.288 \%$ for a male clone with aberrant phenotype. The percentage of methylation for the control group was $44.65 \pm 41.05 \%$ for females and $30.858 \pm 8.928 \%$ for males (Fig.4).

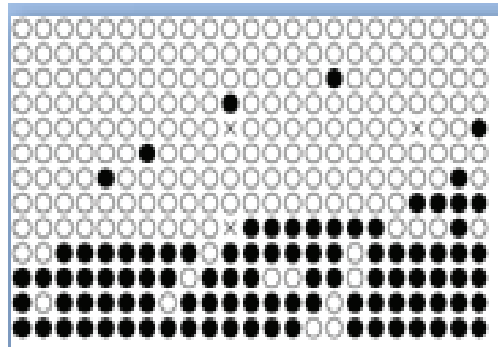

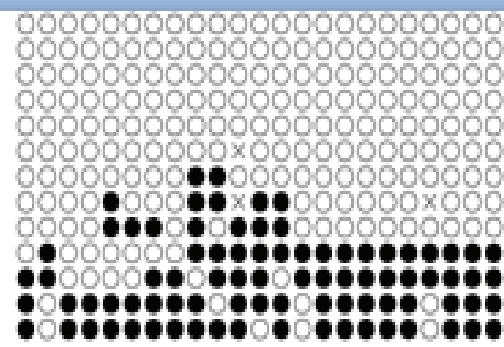

Aberrant male clone $28.584 \pm 9.771$

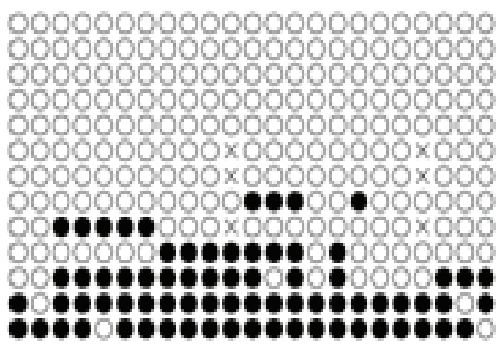

Healthy male clone

$24.907 \pm 9.785 \%$

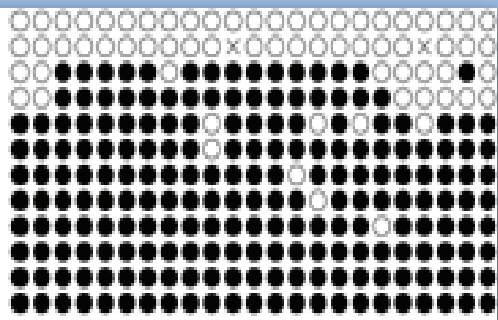

Al male

$75.016 \pm 10.667 \%$
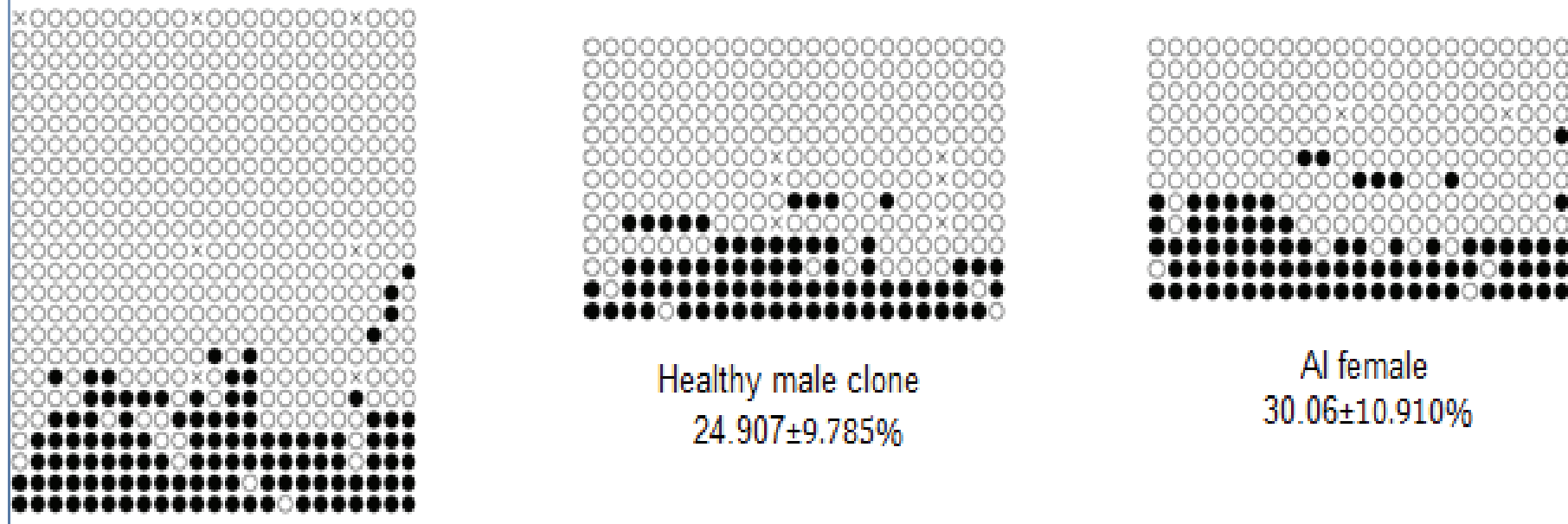

Al female $30.06 \pm 10.910 \%$

\section{Healthy female clone \\ $20.916 \pm 7.016 \%$}

Fig.3. Methylation pattern of ICR/H19 in the placenta (cotyledon) of healthy and aberrant female and male bovine clones, and female and male conceived by artificial insemination (AI, controls). Each line represents one, where each circle is equivalent to a cytosine in the context of $\mathrm{CpG}$ dinucleotide. White circles represent unmethylated cytosines, and black circles represent methylated cytosines. An X represents cytosines that could not be analyzed. The animals and the DNA methylation percentages are represented under each group and were presented as mean. 


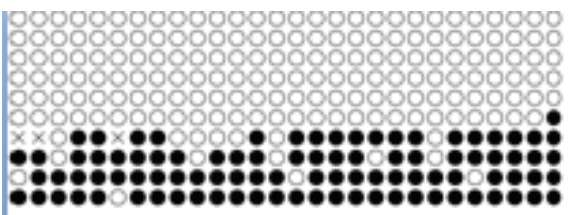

Aberrant female SCNT

$34.34 \pm 13.909 \%$

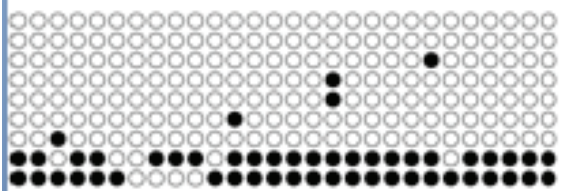

Healthy female SCNT $20.64 \pm 11.928 \%$

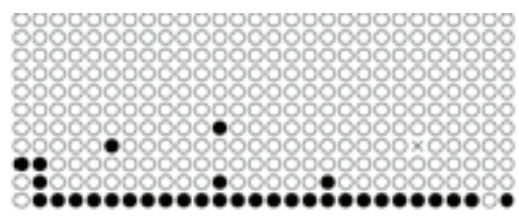

Aberrant male SCNT

$10.72 \pm 8.2880 \%$

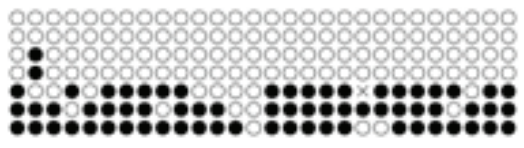

Healthy male SCNT

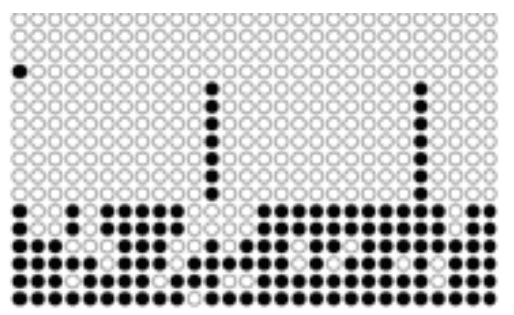

Al male

$30.85 \pm 8.928 \%$

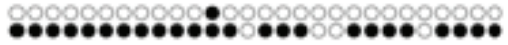

Al female

$44.65 \pm 41.05 \%$

\section{$35.571 \pm 16.065 \%$}

Fig.4. Methylation pattern of exon 10 of the IGF2 gene in the placenta (cotyledon) of healthy and aberrant female and male bovine clones, and females and males conceived by artificial insemination (AI, controls). Each line represents one, where each circle is equivalent to a cytosine in the context of CpG dinucleotide. White circles represent unmethylated cytosines, and black circles represent methylated cytosines. An X represents cytosines that could not be analyzed. The animals and the DNA methylation percentages are represented under each group and were presented as mean.

ICR

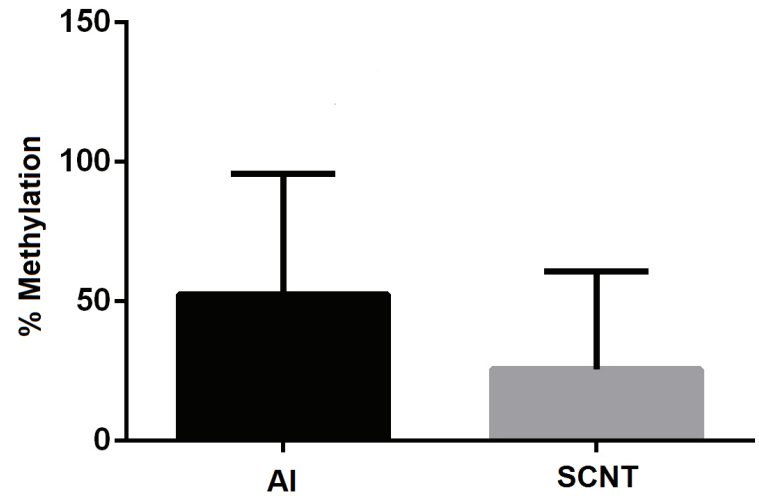

Fig.5. Methylation rate for the ICR/H19 region. Each bar represents a group studied: AI (controls by artificial insemination) and Somatic Cell Nuclear Transfer (SCNT, all clones studied for ICR/ H19-aberrant and healthy). The results are represented as mean \pm standard deviation from the mean $(p<0.05)$.

According to the results obtained for the ICR/H19 region, the control animals, as predicted by the literature, obtained, on average, a methylation pattern of approximately 50\%, while the clones are less methylated (Fig.5 and 7).

Furthermore, individualizing the comparison of clones with controls, H19 of ICR was found in placenta calf clones, a significant difference from controls only with healthy phenotype clones (0.0089) (Fig.6 and 7), the other clones did not show significant differences in the control. When comparing the aberrant clones and healthy clones, for the H19 of ICR, there was no significant difference in the methylation pattern (Fig.6 and 7).

Evaluating the methylation pattern of exon 10 of IGF2 in the placenta of clones compared to the control group conceived by artificial insemination, there was no significant

\section{ICR}

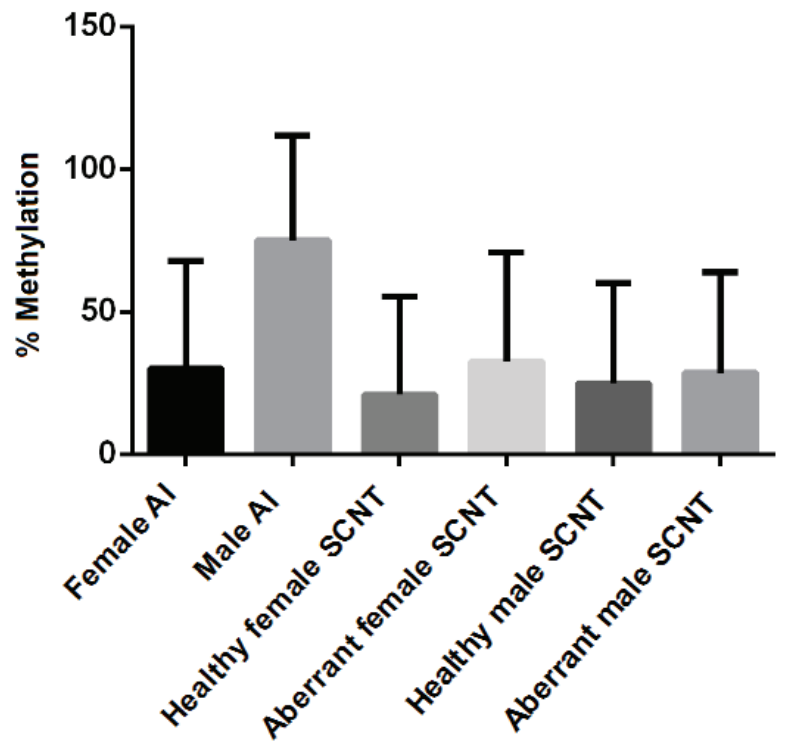

Fig.6. Methylation rate for the ICR/H19 region. Each bar represents a studied group: female artificial insemination (AI), male AI, healthy female Somatic Cell Nuclear Transfer (SCNT), aberrant female SCNT, healthy male TNCS and, aberrant male SCNT. The results are represented as mean \pm standard deviation from the mean $(p<0.05)$.

difference between them (Fig. 8 and 10). The comparison of the methylation pattern of aberrant clone $\mathrm{X}$ healthy clone, for exon 10 of IGF2, also had no significant changes (Figures 9 and 10). However, a hypomethylated pattern can be observed in the aberrant clones for the exon 10 region of IGF2 (Fig.8-10).

The methylation pattern of both ICR/H19 and exon 10 of IGF2 for the clones used in this study showed a lesser methylated pattern than the controls (Fig.11-13). 


\section{DISCUSSION}

Despite the significant advance of the nuclear transfer cloning technique, its efficiency remains low (Rodriguez-Osorio et al. 2012). It is possible to verify high rates of losses during the whole pregnancy and after birth in several species due to placental disorders and aberrant phenotypes in clone animals (Chavatte-Palmer et al. 2004). Among the several disorders that clones present in their embryonic attachments are: very thick umbilical cord, edema in the placenta, large placentomas (Hashizume et al. 2002). The leading cause of these problems in fetuses and their placentas is believed to be related to epigenetic errors involved in embryonic

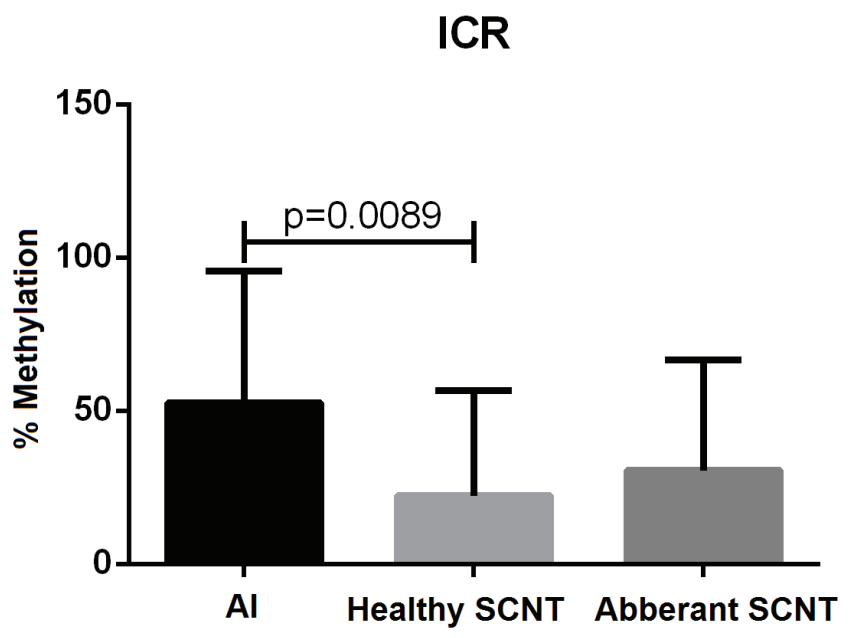

Fig.7. Methylation standard for the ICR/H19 region. Each bar represents a studied group: artificial insemination (AI), healthy Somatic Cell Nuclear Transfer (SCNT), aberrant SCNT. The results are represented as mean \pm standard deviation from the mean $(p<0.05)$.

\section{IGF2}

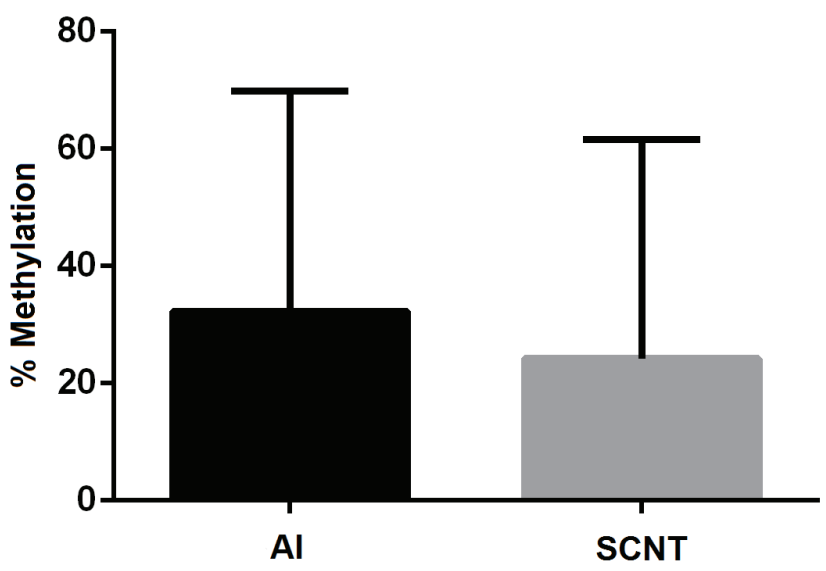

Fig.8. Methylation rate for exon 10 region of IGF2. Each bar represents a group studied: AI (controls by artificial insemination) and, Somatic Cell Nuclear Transfer (SCNT, all clones studied for exon 10 of IGF2 - aberrant and healthy). The results are represented as mean \pm standard deviation from the mean $(p<0.05)$. development, such as failures in the nuclear reprogramming process (Chavatte-Palmer et al. 2004). For example, genomic imprinting is indispensable for the individual's normal development (Reik et al. 2003). If not established correctly, it can damage the regulation of growth and development of the fetus and the placenta (Reik et al. 2003).

\section{IGF2}

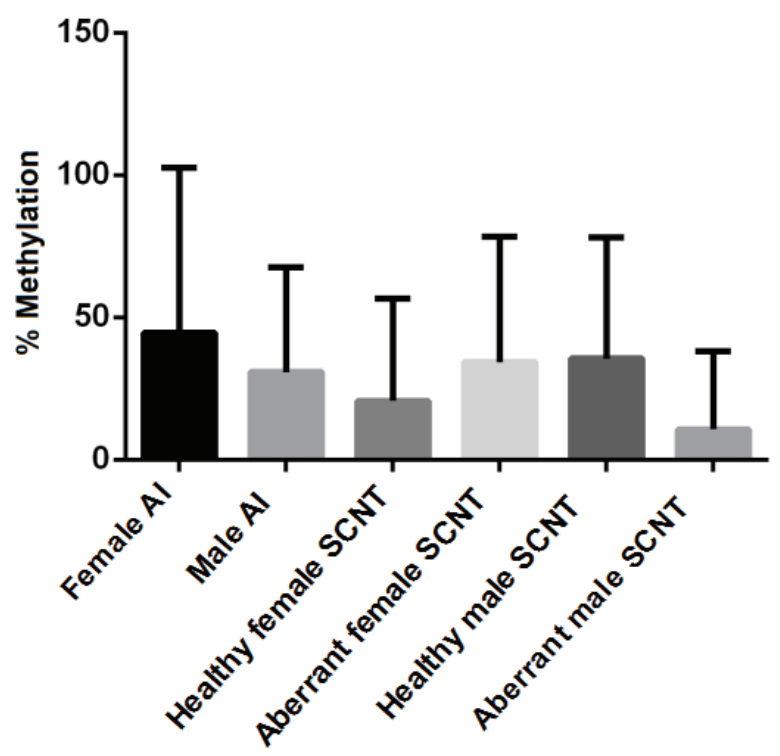

Fig.9. Methylation rate for exon 10 region of IGF2. Each bar represents a studied group: female artificial insemination (AI), male AI, healthy female Somatic Cell Nuclear Transfer (SCNT), aberrant female SCNT, healthy male SCNT, and aberrant male SCNT. The results are represented as mean \pm standard deviation from the mean $(p<0.05)$.

\section{IGF2}

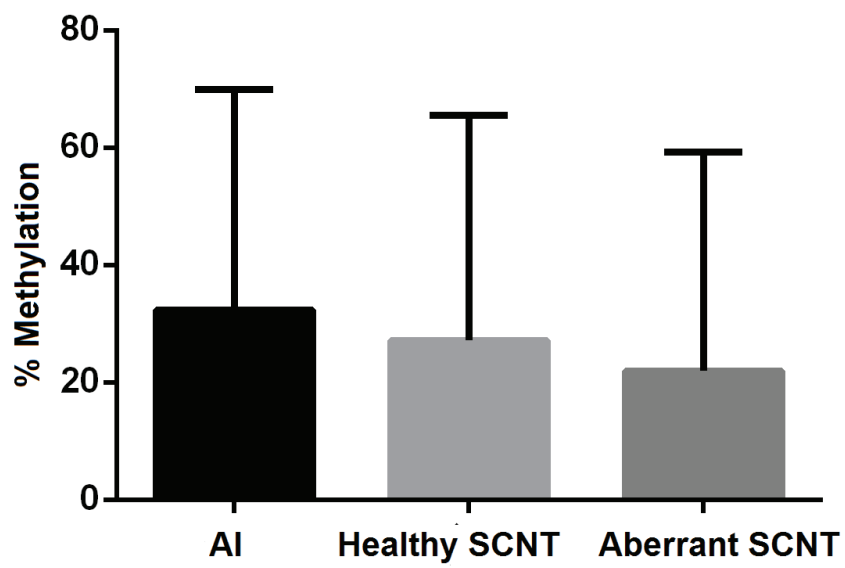

Fig.10. Methylation pattern for the exon 10 region of IGF2. Each bar represents a studied group: artificial insemination (AI), healthy Somatic Cell Nuclear Transfer (SCNT), aberrant SCNT. The results are represented as mean \pm standard deviation from the mean $(p<0.05)$. 
According to the results of this work, when comparing the methylation pattern of all clones with the control animals (conceived by artificial insemination), for the ICR/H19 region, we observed an imprinted pattern in the control animals with a percentage methylation rate of around $50 \%$. This methylation pattern can be confirmed in the study by Park et al. (2009) with somatic pig cells, specifically the lung tissue, a hemimethylated pattern, proving an imprinted model, with the expression of only one allele depending on the parental origin. On the other hand, in that study, the clones were less methylated. As already shown in other works, this pattern may be due to incomplete reprogramming that occurs in clones, which may be the cause of the technique's low

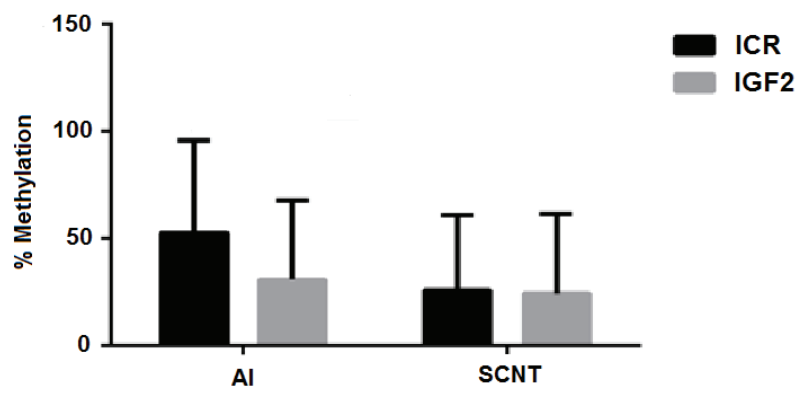

Fig.11. Comparison between methylation rate for the IC19 region of H19 and exon 10 of IGF2. Each bar represents a group studied: AI (controls by artificial insemination) and Somatic Cell Nuclear Transfer (SCNT, all clones studied for the two regions). The results are represented as mean \pm standard deviation from the mean $(p<0.05)$.

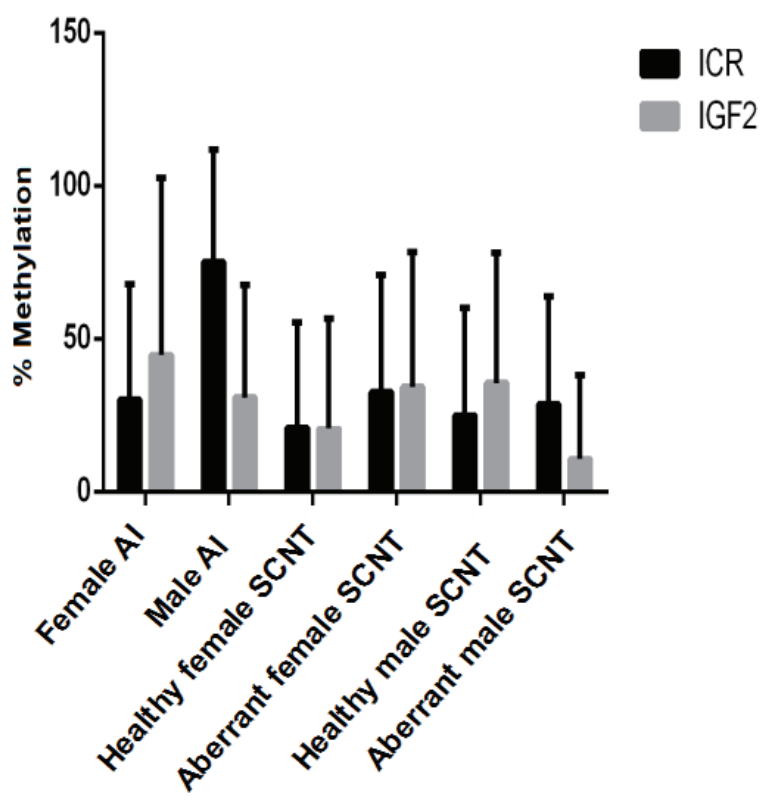

Fig.12. Comparison of the methylation rate for the ICR region of H19 and Exon 10 of IGF2. Each bar represents a studied group: female artificial insemination (AI), male AI, healthy female Somatic Cell Nuclear Transfer (SCNT), aberrant female SCNT, healthy male SCNT, and aberrant male SCNT, for both regions. The results are represented as mean \pm standard deviation from the mean $(p<0.05)$. efficiency. (Xuexiong et al. 2017). In the work of Xuexiong et al. (2017), with fibroblasts from cloned porcine fetuses, while the controls (originated from natural fertilization) showed a $50 \%$ methylated pattern for that same region, the clones were evaluated using a hypomethylated methylation pattern. In the study by Silveira et al. (2018), in satellite, I, the placenta of cloned calves also showed less methylated than control animals.

In the study by Yang et al. (2005), with neonatal bovine clones, half of the animals showed a significant increase in the pattern of H19 expression; that is, the H19 ICR that controls this region was little methylated in these clones, as we found in our study. As has already been reported, the biallelic expression of this same gene (Zhang et al. 2004).

In the study of Yamazaki (2006) on the mechanism of genomic imprinting in the placenta of bovine clones, he found an incomplete nuclear reprogramming in the placenta of viable term-born clones. What may justify this work is that the controls present a significant difference in clones with healthy phenotypes for the region of ICR/H19.

No significant difference was found for exon 10 of IGF2 between controls $\mathrm{X}$ clones and aberrant clones $\mathrm{X}$ healthy clones. The drop in IGF2 activity in bovine placentas can lead to placental abnormalities, such as decreased numbers of placentomas, hypovascularization of the placenta, and rudimentary development of some placental attachments (Yamazaki 2006). However, its elevation can lead to a range of syndromes, such as Beckwith-Wiedemann syndrome (BWS), characterized by exacerbated growth (Engel et al. 2000, Robbins et al. 2012). Probably, with a larger sample number, a significant difference would be found between the groups evaluated here in this study.

The study by Yamazaki (2006) revealed that a significant change in the pattern of expression of the H19 and IGF2 genes was revealed in the placenta of bovine clones compared to controls, with less expression of these "imprinted" genes, contributing to increased postnatal mortality. The rate of loss is believed to be a consequence of placental disorders, which

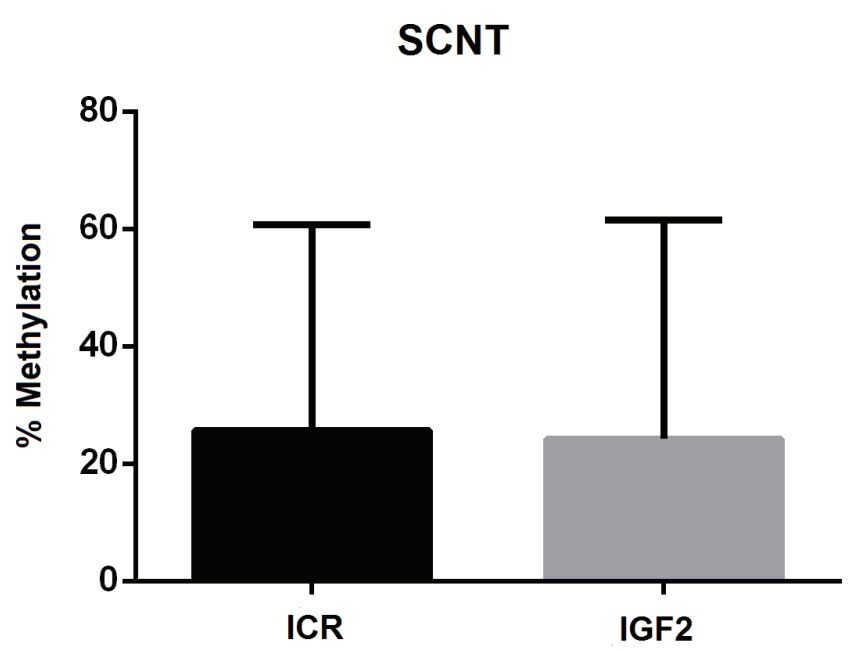

Fig.13. Comparison of the methylation pattern of the clones selected for the ICR/H19 region and of the clones selected for the exon 10 region of IGF2. The results are represented as mean \pm standard deviation $(p<0.05)$. Somatic Cell Nuclear Transfer (SCNT). 
can be explained by the fact that the placenta is responsible for the exchange of gases and nutrients between mother and fetus, in addition to being important in the implantation process and early recognition of pregnancy by mother (Cross 2006). Therefore, a placenta different from the ideal, with the presence of phenotypic disorders, can interfere more in reprogramming the nucleus and regulating the fetus' gene expression. Contrary to the Yamazaki study, in the placenta of murine clones, an expression pattern for this elevated region was found (Inoue et al. 2002), suggesting a specific species change, including the different placentation process between mice and cattle (Kato et al. 1998, Humpherys et al. 2001).

This study shows a positive correlation between the two regions studied, with similar methylation patterns. Regarding expression, in mice, a negative correlation was found between IGF2 and H19. In many species (Humpherys et al. 2001), different from the study by Yamazaki (2006), it was possible to notice a positive correlation between genes. In the latter case, the decrease in H19 did not lead to an increase in IGF2, suggesting that the mechanism of regulation of imprinted genes may differences between species (Yamazaki 2006) or indicates that IGF2 is not just regulated by H19 even though there are few studies of these genes in the placenta of bovine clones, analysis of tissues from neonates clones and dead clones shortly after birth demonstrated that IGF2 expression patterns were significantly higher than in control calves (Yang et al. 2005). However, in the tissue analysis of newborn sheep clones, no difference was detected to express the IGF2 and H19 genes concerning the controls (Young et al. 2003). There is a diversity in the results of research related to these regions for clones, indicating an incomplete gene reprogramming, varying according to the epigenetic stability of the donor nucleus (Humpherys et al. 2001) or it can also indicate that it is not just these regions that determine success in embryonic development, but rather a set of genes, being well reprogrammed (Chavatte-Palmer et al. 2004).

Although efficient production of bovine clones is possible, a high mortality rate is noted during pregnancies and afterbirths (Chavatte-Palmer et al. 2004), the consequence of a set of factors, which are not reflected only in an incorrect reprogramming of the IGF2 and $\mathrm{H} 19$ genes, located in the study regions, but in an incomplete reprogramming of several genes involved in the development of the placenta (Hill et al. 1999, Heyman et al. 2002, Chavatte-Palmer et al. 2004). Therefore, more information is needed to clarify the epigenetic control mechanism during the development of clone animals.

\section{CONCLUSION}

The low efficiency in Somatic Cell Nuclear Transfer (SCNT) may be related to errors in nuclear reprogramming, mainly for the ICR/H19 region.

\footnotetext{
Acknowledgment.- To "Embrapa Recursos Genéticos e Biotecnologia” for providing the entire structure for carrying out this work. To "Geneal Genética e Biotecnologia Animal", for having given in to the biological samples used in this study.
}

Conflict of interest statement.- The authors have no conflicts of interest to declare.

\section{REFERENCES}

Barlow D.P. \& Bartolomei M.S. 2014. Genomic imprinting in mammals. Cold Spring Harbor Perspectives in Biology, Cold Spring Harbor NY. 6(2)018382. <https://dx.doi.org/10.1101/cshperspect.a018382>

Bartolomei M.S. 2009. Genomic Impression: employing and avoiding epigenetic processes. Genes \& Development, Cold Spring Harbor NY. 23(18):21242133. <https://dx.doi.org/10.1101/gad.1841409><PMid:19759261>

Biase F.H., Franco M.M., Goulart L.R. \& Antunes R.C. 2002. Protocol for extraction of genomic DNA from swine solid tissues. Genet. Mol. Biol., Ribeirão Preto, 25(3):313-315. <https://dx.doi.org/10.1590/S141547572002000300011>

Brannan C.I., Dees E.C., Ingram R.S. \& Tilghman S.M. 1990. The product of the h19 gene may function as na RNA. Mol. Cell. Biol., Washington, 10(1):28-36. <https://dx.doi.org/10.1128/mcb.10.1.28> <PMid:1688465>

Chavatte-Palmer P., Remy D. \& Cordonnier N. 2004. Health status of cloned cattle at different ages. Cloning Stem Cells, Larchmont, 6(2):94-100. <https://dx.doi.org/10.1089/1536230041372274><PMid:15268782>

Cibelli J.B., Stice S.L., Golueke P.J., Kane J.J., Jerry J., Blackwell C., Ponce de León F.A. \& Robl J.M. 1998. Cloned transgenic calves produced from nonquiescent fetal fibroblasts. Science, Washington, 280(5367):1256-1258. <https:// dx.doi.org/10.1126/science.280.5367.1256><Pmid:9596577>

CROSS J.C. 2006 Nutritional influences on implantation and placental development. Nutr. Rev., New York, 64(5 Pt 2):S512-S18. <https://dx.doi. org/10.1301/nr.may.s12-s18> <PMid:16770948>

Daelemans C., Ritchie M.E., Smits G., Abu-Amero S., Sudbery I.M., Forrest M.S., Campino S., Clark T.G., Stanier P., Kwiatkowski D., Deloukas P., Dermitzakis E.T., Tavaré S., Moore G.E. \& Dunham I. 2010. High-throughput analysis of candidate imprinted genes and allele-specific gene expression in the human term placenta. BMC genetics, London, 11:25. <https://dx.doi org/10.1186/1471-2156-11-25> <PMid:20403199>

Dean W., Santos F. \& Reik W. 2003. Epigenetic Reprogramming in early mammalian development and following somatic nuclear transfer. Semin Cell Develop. Biol., Palo Alto, 14(1):93-100.<https://dx.doi.org/10.1016/ s1084-9521(02)00141-6><PMid:12524012>

Dupont C., Armant D.R. \& Brenner C.A. 2009. Epigenetics: definition, mechanisms and clinical perspective. Semin. Semin Reprod. Med., New York, 27(5):351-357. <https://dx.doi.org/10.1055/s-0029-1237423> $<$ PMid:19711245>

Engel J.R., Smallwood A., Harper A., Higgins M.J., Oshimura M., Reik W., Schofield P.N \& Maher E.R. 2000. Epigenotype-phenotype correlations in Beckwith-Wiedemann syndrome. J. Med. Genet., New York, 37(12):921926. <https://dx.doi.org/10.1136/jmg.37.12.921>

Gebert C., Wrenzycki C., Herrmann D., Gröger D., Reinhardt R., Hajkova P., Lucas-Hahn A., Carnwath J., Lehrach H. \& Niemann H. 2006. The bovine IGF2 gene is differentially methylated in oocyte and sperm DNA. Genomics, San Diego, 88(2):222-229. <https://dx.doi.org/10.1016/j.ygeno.2006.03.011>

Hashizume K., Ishiwata H., Kizaki K., Yamada O., Takahashi T., Imai K., Patel O.V., Akagi S., Shimizu M. \& Takahashi S. 2002. Implantation and placental development in somatic cell clone recipient cows. Cloning Stem Cells 4(3):197-209. <https://dx.doi.org/10.1089/15362300260339485> $<$ PMid:12398801>

Heyman Y., Zhou Q., Lebourhis D., Chavatte-Palmer P., Renard J.P. \& Vignon X. 2002. Novel approaches and hurdles to somatic cloning in cattle. Cloning Stem Cells, Larchmont, 4(1):47-55. <https://dx.doi. org/10.1089/153623002753632048> <PMid:12006156>

Hill J. R., Roussel A.J., Cibelli J.B., Edwards J.F., Hooper N.L., Miller M.W., Thompson J.A., Looney C.R., Westhusin M. E., Robl J.M. \& Stice S.L. 1999. Clinical and pathologic features of cloned transgenic calves and fetuses (13 case studies). Theriogenology, Stoneham, 51(8):1451-1465.<https:// dx.doi.org/10.1016/s0093-691x(99)00089-8><PMid:10729073> 
Humpherys D., Eggan K., Akutsu H., Hochedlinger K., Rideout W.M., Biniszkiwicz D., Yanagimachi R. \& Jaenisch R. 2001. Epigenetic instability in ES cells and cloned mice. Science, Washington, 293(5527):95-97. <https://dx.doi. org/10.1126/science.1061402> <PMid:11441181>

Inoue K., Kohda T., Lee J., Ogonuki N., Mochida K., Noguchi Y., Tanemura K., Kaneko-Ishino T., Ishino F. \& Ogura A. 2002. Faithful expression of imprinted genes in cloned mice. Science, Washington, 295(5553):297. <https://dx.doi.org/10.1126/science.295.5553.297><Pmid:11786635>

Jena S.C., Kumar S., Rajput S., Roy B., Verma A., Kumaresan A., Mohanty T.K., Rakesh Kumar S. \& Datta T.K. 2014. Differential methylation status of IGF2-H19 locus does not affect the fertility of crossbred bulls but some of the CTCF binding sites could be potentially important. Mol Reprod Dev. New York, 81(4):350-362.<https://dx.doi.org/10.1002/mrd.22303><PMid:24436206>

Kato Y., Tani T., Sotomaru Y., Kurokawa K., Kato J., Doguchi H., Yasue H. \& Tsunoda Y. 1998. Eight calves cloned from somatic cells of a single adult. Science, Washington, 282(5396):2095-2098. <https://dx.doi.org/10.1126/ science.282.5396.2095><PMid:9851933>

Lucifero D., Mann M.R.W., Bartolomei M.S. \& Trasler J.M. 2004.Gene-specific timing and epigenetic memory in oocyte imprinting. Human Mol. Genet. Oxford, 13(8):839-849. <https://dx.doi.org/10.1093/hmg/ddh104>

Mann M.R., Chung Y.G., Nolen L.D., Verona R.I., Latham K.E. \& Bartolomei M.S. 2003. Disruption of imprinted gene methylation and expression in cloned preimplantation stage mouse embryos. Biol. Reprod., New York, 69(3):902-914. <https://dx.doi.org/10.1095/biolreprod.103.017293> $<$ PMid:12748125>

Migicovsky Z. \& Kovalchuk I. 2011. Epigenetic memory in mammals. Front. Genet. 2:1-7. <https://dx.doi.org/10.3389/fgene.2011.00028> $<$ PMid:22303324>

Murrell M., Heeson S., Bowden L., Constância M., Dean W., Leksey G. \& Reik W. 2001. An intragenic methylated region in the imprinted igf2 gene augments transcriptions. EMBO Reports, London, 2(12)1101-1106. <https://dx.doi. org/10.1093/embo-reports/kve248><PMid:11743023>

O'dell S.D. \& Day I.N. 1998. Molecules in focus Insulin-like growth factor II (IGF-II). Int. J. Biochem. Cell Biol. 30(7):767-771. <https://dx.doi. org/10.1016/S1357-2725(98)00048-X>

Park C.H., Kim H.S., Lee S.G. \& Lee C.K. 2009. Methylation status of differentially methylated regions at Igf2/H19 locus in porcine gametes and preimplantation embryos. Genomics, San Diego, 93(2):179-186. <https://dx.doi.org/10.1016/j.ygeno.2008.10.002> <PMid:18983907>

Petersen B. 2017. Basics of genome editing technology and its application in livestock species. Reprod. Domest. Anim., Zuchthygiene, 52(Supl.3):4-13. <https://dx.doi.org/10.1111/rda.13012> <PMid:28815851>

Reik W. 2007. Stability and flexibility of epigenetic gene regulation in mammalian development. Nature, London, 24:425-432. <https://dx.doi. org/10.1038/nature05918><PMid:17522676>

Reik W., Constancia M., Fowden A., Anderson N., Dean W., Ferguson-Smith A., Tycko B. \& Sibley C. 2003. Regulation of supply and demand for maternal nutrients in mammals by imprinted genes. J. Physiology, Bethesda, 547(Pt 1):35-44. <https://dx.doi.org/10.1113/jphysiol.2002.033274> $<$ PMid:12562908>

Robbins K.M., Chen Z., Wells K.D. \& Rivera R.M. 2012. Expression of KCNQ10T1, CDKN1C, H19, and PLAGL1 and methylation patterns with the KvDMR1 and H19/IGF2 imprinting control regions is conserved between human and bovine. J Biomed Sci. 19:95.<https://dx.doi.org/10.1186/1423-0127-19-95> <PMid:23153226>

Rodriguez-Osorio N., Urrego R., Cibelli J.B., Eilertsen K. \& Memili E. 2012. Reprogramming mammalian somatic cells. Theriogenology, Stoneham, 78(9):1869-1886. <https://dx.doi.org/10.1016/j.theriogenology.2012.05.030> $<$ PMid:22979962>

Silveira M.M., Salgado B., Henrique X., Dos Santos M.A., Borges N.A., Vargas L.N., Caetano A.R., Rumpf R. \& Franco M.M. 2018. DNA methylation profile at a satellite region is associated with aberrant placentation in cloned calves. Placenta, Washington, 70:25-33. <https://dx.doi.org/10.1016/j. placenta.2018.08.007>

Smith L.C., Suzuki J., Goff A.K., Filion F., Therrien J., Murphy B.D., KohanGhadr H.R., Lefebvre R., Brisville A.C., Buczinski S., Fecteau G., Perecin F. \& Meirelles F.V. 2012. Developmental and epigenetic anomalies in cloned cattle. Reprod. Domest. Anim., Berlin, 47(Supl.4):107-114. <https://dx.doi. org/10.1111/j.1439-0531.2012.02063.x><PMid:22827358>

Smith Z.D. \& Meissner A. 2013. DNA methylation: roles in mammalian development. Nat. Rev. Genet., London, 14(3):204-220. <https://dx.doi. org/10.1038/nrg3354><PMid:23400093>

Urrego R., Rodriguez-Osorio N. \& Niemann H. 2014.Epigenetic disorders and altered gene expression after use of Assisted Reproductive Technologies in domestic cattle. Epigenetics Chromatin, London, 9(6):803-815.<https:// dx.doi.org/10.4161/epi.28711><PMid:24709985>

Vargas L.M. 2018. Perfil transcricional de genes relacionados com a reprogramação da metilação do DNA em placenta de bovinos clones. Master's Thesis in Genetics and Biochemistry, Instituto de Genética e Bioquímica, Universidade Federal de Uberlândia. Avalaible at <https://repositorio. ufu.br/bitstream/123456789/22391/3/PerfilTranscricionalGenes.pdf> Accessed on Dec. 15, 2018.

Wells D.N., Misica P.M. \& Tervit H.R. 1999. Production of cloned calves following nuclear transfer with cultured adult mural granulosa cells. Biol. Reprod., New York, 60(4):996-1005. <https://dx.doi.org/10.1095/ biolreprod60.4.996><PMid:10084977>

Wilmut I., Schnieke A.E., Mcwhir J., Kind A.J. \& Campbell K.H.S. 1997. Viable offspring derived from fetal and adult mammalian cells. Nature, London, 385(6619):810-813. <https://dx.doi.org/10.1038/385810a0> <PMid:9039911>

Xuexiong S., Li F., Jiang Z., Sun Y., Li H., Gao S., Zhang L., Xue B., Zhao G., Li J., Liu Z., He H. \& Huan Y. 2017. Imprinting disorder in donor cells is detrimental to the development of cloned embryos in pigs. Oncotarget, London, 8(42)72363-72374. <https://dx.doi.org/10.18632/oncotarget.20390> <PMid:29069793>

Yamazaki W. 2006. Estudo do "genomic imprinting" na placenta de clones bovinos. Doctoral Dissertation in Veterinary Sciences, Faculdade de Ciências Agrárias e Veterinárias, Universidade Estadual Paulista, Availabe at <http://fcav.unesp.br/download/pgtrabs/ra/d/1263.pdf> Accessed on Mar. 2, 2019.

Yang L., Chavatte-Palmer P., Kubota C., O'Neill M., Hoagland T., Renard J.P., Taneja M., Yang X. \& Tian X.C. 2005. Expression of imprinted genes is aberrant in deceased newborn cloned calves and relatively normal in surviving adult clones. Biol. Reprod., New York, 71(4):431-438. <https://dx.doi.org/10.1002/mrd.20311><PMid:15895469>

Young L.E., Schnieke A.E., Mccreath K.J., Wieckowski S., Konfortova G., Fernandes K., Ptak G., Kind A.J., Wilmut I., Loi P. \& Feil R. 2003. Conservation of IGF2-H19 and IGF2R imprinting in sheep: effects of somatic cell nuclear transfer. Mechanisms Develop., Limerick. 120(12):1433-1442. <https://dx.doi.org/10.1016/j.mod.2003.09.006>

Zhang J., Qu P., Zhou C., Liu X., Ma X., Wang M., Wang Y., Su J., Liu J. \& Zhang Y. 2017. MicroRNA-125b is a key epigenetic regulatory factor that promotes nuclear transfer reprogramming. J. Biol. Chemistry, Rockville, 292(38):15916-15926.<https://dx.doi.org/10.1074/jbc.M117.796771> <PMid:28794155>

Zhang S., Chen X., Wang F., An X., Tang B., Zhang X., Sun L. \& Li Z. 2016. Aberrant DNA methylation reprogramming in bovine SCNT preimplantation embryos. Scient. Rep., London, 6:30345. <https://dx.doi.org/10.1038/ srep30345><PMid:27456302>

Zhang S., Kubota C., Yang L., Zhang Y., Page R., O'Neill M., Yang X. \& Tian X.C. 2004. Genomic imprinting of H19 in naturally reproduced and cloned cattle. Biol. Reprod., New York, 71(5):540-1544. <https://dx.doi.org/10.1095/ biolreprod.104.031807><PMid:15240429> 